\title{
Composition of acacia honeys following processing, storage and adulteration
}

\author{
Nikolett Czipa $^{1}$ - Clive J. C. Phillips ${ }^{2}$ Béla Kovács ${ }^{1}$
}

Revised: 9 January 2019/Accepted: 14 January 2019/Published online: 28 January 2019

(C) The Author(s) 2019

\begin{abstract}
This study investigated the effect of different treatments (centrifugation and filtration; heating; adulteration with sugar syrups, and storage) and collection variables (year and region of the country) on the physicochemical properties of 44 Hungarian acacia honeys. The characteristics measured were diastase activity, hydroxyl-methyl-furfural (HMF), total phenolic content (TPC), electrical conductivity (EC), colour, $\mathrm{pH}$, proline, moisture, sucrose, fructose and glucose contents, and concentration of eleven elements (As, B, Cd, Cr, Fe, K, $\mathrm{Mg}, \mathrm{Na}, \mathrm{P}, \mathrm{S}, \mathrm{Zn}$ ). Centrifugation and filtration reduced the concentration of all examined parameters, except for moisture. Heating reduced diastase activity, proline and total phenolic concentrations and increased HMF concentration and colour value. Adulteration with sugar syrups had adverse effects on the diastase activity, proline, moisture and sugar concentrations, EC, colour and $\mathrm{pH}$. Two-year storage reduced diastase activity, HMF, proline and TPC concentrations and increased sucrose concentrations. The collecting area influenced $\mathrm{Na}, \mathrm{Fe}$ and As concentration, but the collecting year had no effect on the examined parameters. It is concluded that method and region of honey collection, duration of storage and processing all have major effects on the quality of acacia honey. Applied sugar syrup, although it affected honey quality, would be difficult to detect in the finished product.
\end{abstract}

Nikolett Czipa

nikolettczipa@gmail.com

1 Institute of Food Science, Faculty of Agricultural and Food Sciences and Environmental Management, University of Debrecen, Böszörményi Street 138, Debrecen 4032, Hungary

2 School of Veterinary Science, University of Queensland, Gatton, QLD 4343, Australia
Keywords Acacia honey · Heating · Adulteration · Centrifugation $\cdot$ Collection

\section{Introduction}

Honey is a natural substance produced by Apis mellifera from flower nectar and honeydew. Hungary, which has favourable environmental and geographical conditions for honey production, made 24,000 tons in 2016 (KSH 2016), of which about 15,000 tons was exported. The most important honey types are from the flowers of acacia, sunflower, lime, silk grass and rape in Hungary. Honey is a very complex food and its properties depend on the botanical, environmental and treatment (storage, extraction techniques, etc.) conditions. In Hungary, the climatic and geographical conditions are excellent suitable for honey production. Honey is a good environmental indicator (Almeida-Silva et al. 2011) because the element content of soil, water and air in the collecting area can influence the element properties of honey. The determination of potentially toxic heavy metal concentrations is particularly important because of its relation to the environment. Electrical conductivity is also useful to determine because it has a strong correlation with mineral salts (Terrab et al. 2002), especially potassium (Guler et al. 2007). In the European Union, electrical conductivity in blossom honeys should have a maximum of $0.8 \mathrm{mS} / \mathrm{cm}$ (Council Directive 2001/110/EC, hereafter the EU Directive). Honey has an amino acid content of about $1 \%$ of dry matter, with the most important being proline $(50-85 \%$ of total amino acids, Anklam 1998). A proline content of $180 \mathrm{mg} / \mathrm{kg}$ is the minimum value that is internationally recommended (Hermosín et al. 2003). According to Oddo and Bogdanov (2004), proline and electrical conductivity are the most 
important parameters to indicate the botanical origin of honey.

The three main enzymes in honey are diastase (amylase), invertase (sucrose) and glucose oxidase (Bogdanov et al. 2008). The quantity of diastase and invertase is variable in fresh honey and is indicative of the composition and concentration of nectar. Values also decrease after storage and heating (Tosi et al. 2008). According to the EU Directive the minimum diastase activity should be $8 \mathrm{DN}$.

Honey contains glucose, fructose, sucrose and about 25 different oligosaccharides (Doner 1977). In most honey types fructose prevails and glucose is the second most important sugar (Cavia et al. 2002). One of the most important sugars in relation to adulteration of honey is sucrose; however the content of this dissacharide is also influenced by the weather (Lampeitl and Franz 1997). According to EU Directive the minimum fructose and glucose content-determined as the sum of both in blossom honeys-is $60 \%$ and the maximum sucrose content is $10 \%$ in the case of false acacia.

Beekeepers often heat honey before packaging, with the reference temperature being $40^{\circ} \mathrm{C}$, even though higher temperatures may be applied. This reduces the specific gravity and increases ash content, $\mathrm{pH}, \mathrm{HMF}$, browning, phenolics and antioxidant activity. Hydroxy-methyl-furfural (HMF) is a cyclic aldehyde that is generated from fructose in the presence of acid. Fresh honey has zero or trace HMF, and the formation of HMF is very slow, as long as the temperature and period of storage is correct (White 2000). However, heating can accelerate the speed of formation, as can adulteration with invert sugar (Nozal et al. 2001). According to the EU Directive the maximum HMF content in honey is $40 \mathrm{mg} / \mathrm{kg}$. Moisture content affects the storage life of honeys because too high a moisture content facilitates the fermentation process. According to the EU Directive the maximum moisture content is $20 \%$.

The aims of this study were to: (1) determine the effect of centrifuging and filtration on the physicochemical parameters of acacia honeys; (2) determine the effect of heating on the physicochemical parameters of acacia honeys; (3) examine the effects of adulteration of acacia honeys samples with different sugar products; (4) examine the effects of collecting year and collecting area on the composition of acacia honey; (5) determine the effect of 2 years' storage on the physicochemical parameters of acacia honeys.

\section{Materials and methods}

\section{Samples}

Forty-four acacia (Robinia pseudoacacia) honey samples, collected directly from beekeepers, were examined to determine physicochemical parameters: storage, centrifuging and filtration, collecting year and area, heating and adulteration with different sugar products. Three samples to be used for a study of the effects of centrifugation and filtration and one for studying adulteration and heating were collected in 2016. For examination of the effect of centrifuging and filtration, honey samples were collected from three counties of Hungary (Sample 1 from Hajdú-Bihar County, Sample 2 from Szabolcs-SzatmárBereg County and Sample 3 from Békés County). One-one honeycomb was chosen from each hive of these counties. After the removal of wax-capping the samples were taken directly from honeycomb, before individual centrifuging and filtration. For studying adulteration and heating one hive of Békés County was chosen and the sampling was carried out after the centrifuging and filtration of all of honeycombs from this hive. Inter-annual variations were examined using samples collected in 2014, 2015 and 2016. Five acacia honey samples collected in 2015 were used for the examination of 2-year storage. All samples (1000 g) were collected immediately after centrifuging and filtration in new, sterile glass jars and these samples were storage in the dark at room temperature $\left(20^{\circ} \mathrm{C}\right)$. Acacia pollens, wax cuppings and combs from beekeepers were also examined. Acacia pollens were collected directly from pollen traps, wax cupping and comb pieces were collected immediately from removal of wax cupping. Melissopalynological analysis was carried out to verify the botanical origin of honeys using the method described by MSZ 6950-3:1977 (microscopic analysis of honey) [13]. The acacia pollen proportion was higher than $50 \%$ in every examined honey sample.

\section{Treatments}

The effects of centrifugation and filtration were examined with three acacia honey samples from three apiaries. From three hives in each, $1000 \mathrm{~g}$ honey samples were taken before and after centrifugation and filtration into new, sterile glass jars. Beside honey samples, acacia pollen grains, wax cuppings and combs were sampled from the same hives as the honey samples. Fresh acacia honey subsamples of $100 \mathrm{~g}$ were then placed into closed glass vessels followed by heating to $40,50,60,70$ or $80{ }^{\circ} \mathrm{C}$ for a $60 \mathrm{~min}$ period in a water bath (Bandelin Sonorex Digital 
DT $255 \mathrm{H}$, Germany). Time measurement started when the temperature of the honey reached the required temperature.

Adulteration of the honey samples was with glucose syrup (GS), fructose-glucose syrup (FGS), invert sugar 1 (ISA) and invert sugar 2 (ISE). GS and FGS were obtained directly from the producer (Hungrana Ltd., Hungary). FGS was produced by hydrolysis of starch. GS is a purified and concentrated aqueous solution of polysaccharides, also produced by hydrolysis of starch. ISA was produced by acid hydrolysis of sucrose, with sugar, water and ascorbic acid heated together at $114^{\circ} \mathrm{C}$. ISE was produced by enzymatic hydrolysis with invertase enzyme (SigmaAldrich Kft., Budapest, Hungary) added to $70 \%$ sucrose solution. The enzyme was inactivated by heating at $80^{\circ} \mathrm{C}$ for $10 \mathrm{~min}$. The pure honey samples were then adulterated with GS, GFS, ISA and ISE at levels of $30 \%$ and $40 \%$. The adulteration and the invert sugar (ISA and ISE) preparations were carried out in an accredited laboratory (ISO/IEC 17025:2005). Honey samples for examination of storage were kept in the dark at room temperature in closed glass vessels.

\section{Analytical methods}

All chemicals were analytical grade or better. Ultrapure water was used to prepare of solutions and dilutions produced by a Milli-Q water purification system (Millipore S.A.S., Molsheim, France).

The digestion of samples for element analysis was carried out according to the method of Kovács et al. (1996), which has been validated using animal and plant materials in our accredited laboratory. A total of $3 \mathrm{~g}$ honey was added to $10 \mathrm{ml}$ nitric acid $(69 \% \mathrm{v} / \mathrm{v}$; VWR International Ltd., Radnor, USA) and the samples allowed to stand overnight. Samples were pre-digested at $60{ }^{\circ} \mathrm{C}$ for $30 \mathrm{~min}$. After cooling, $3 \mathrm{ml}$ hydrogen-peroxide $(30 \% \mathrm{v} / \mathrm{v}$; VWR International Ltd., Radnor, USA) was added and the samples heated at $120{ }^{\circ} \mathrm{C}$ for $90 \mathrm{~min}$. After digestion, ultrapure water was added to make a final volume of $50 \mathrm{ml}$. Samples were homogenized and filtered using qualitative filter papers (Sartorius Stedim Biotech S.A., Gottingen, Germany). The concentrations of boron, potassium, magnesium, sodium, phosphorus and sulphur were determined by ICP-OES (Inductively Coupled Plasma Optical Emission Spectrometer) (Thermo Scientific iCAP 6300, Cambridge, UK). The applied wavelengths were the following: 249.772 for B, 769.896 for $\mathrm{K}, 279.806$ for $\mathrm{Mg}, 818.326$ for $\mathrm{Na}$, 213.617 for $\mathrm{P}$ and 182.563 for sulphur. Detection limits (DL) of ICP-OES were: $0.0004 \mathrm{mg} / \mathrm{kg}$ for $\mathrm{B}, 0.527 \mathrm{mg} / \mathrm{kg}$ for $\mathrm{K}, 0.104 \mathrm{mg} / \mathrm{kg}$ for $\mathrm{Mg}, 0.009 \mathrm{mg} / \mathrm{kg}$ for $\mathrm{Na}, 0.489 \mathrm{mg} /$ $\mathrm{kg}$ for $\mathrm{P}$ and $0.108 \mathrm{mg} / \mathrm{kg}$ for $\mathrm{S}$. The determination of arsenic, cadmium, chromium, iron and zinc was carried out using ICP-MS (Inductively Coupled Plasma Mass
Spectrometry) (Thermo Scientific XSeries 2, Bremen, Germany). Measured isotopes (amu) were as follows: 75 for $\mathrm{As}, 111$ for $\mathrm{Cd}, 52$ for $\mathrm{Cr}, 56$ for $\mathrm{Fe}$ and 66 for $\mathrm{Zn}$. Detection limits (DL) of ICP-MS were: $0.019 \mu \mathrm{g} / \mathrm{kg}$ for As, $0.003 \mu \mathrm{g} / \mathrm{kg}$ for $\mathrm{Cd}, 0.38 \mu \mathrm{g} / \mathrm{kg}$ for $\mathrm{Cr}, 0.017 \mu \mathrm{g} / \mathrm{kg}$ for Fe and $0.004 \mu \mathrm{g} / \mathrm{kg}$ for $\mathrm{Zn}$.

Moisture contents (in \%) were determined by refractometry (AOAC 1995a, 969.38) using a Medline DIGIT 5890 ATC Honey Pocket refractometer (United Kingdom). Electrical conductivity (EC, in $\mu \mathrm{S} / \mathrm{cm}$ ) was determined according to the method of Bogdanov et al. (1997) in a $20 \%(\mathrm{w} / \mathrm{v})$ solution of honey (in distilled water) using a conductometer (FiveEasy ${ }^{\mathrm{TM}}$ FE30, Mettler-Toledo AG, Switzerland). The $\mathrm{pH}$ values were measured in a $30 \%(\mathrm{w} / \mathrm{v})$ solution of honey (in distilled water) with a $\mathrm{pH}$ meter (FiveEasy $^{\text {TM }}$ FE20, Mettler-Toledo AG, Switzerland), according to the MSZ 6943-3:1980 standard.

Diastase activity was determined following the spectroscopic method of Bogdanov (2009), using a spectrophotometer (Evolution 300 LC, Thermo Electron Corporation, England) at $660 \mathrm{~nm}$. Applied reagents were iodine (VWR International BVBA, Leuven, Belgium), potassium iodide, sodium acetate, acetic-acid, sodium chloride and starch (Sigma-Aldrich Chemie $\mathrm{GmbH}$, Steinheim, Germany). Diastase activity is expressed as a diastase number (DN). Determination of the hydroxylmethyl-furfural (HMF) content of samples in $\mathrm{mg} / \mathrm{kg}$ was based on the White method (Bogdanov 2009). Applied reagents were potassium hexacyanoferrate (II) trihydrate for Carrez I. and zinc acetate for Carrez II (VWR International BVBA, Leuven, Belgium) and sodium disulfite (AppliChem GmbH, Darmstadt, Germany). Proline content in $\mathrm{mg} / \mathrm{kg}$ was measured using a spectrometric assay (Bogdanov 2009) with a spectrophotometer (Evolution 300 LC, Thermo Electron Corporation, England) at $510 \mathrm{~nm}$. Applied reagents were formic acid (Sigma-Aldrich Chemie GmbH, Steinheim, Germany), ninhidrin, methoxyethanol, L-proline (Alfa Aesar GmbH \& Co. KG, Karlsruhe, Germany) and 2-propanol (Sigma-Aldrich Chemie $\mathrm{GmbH}$, Steinheim, Germany). TPC in $\mathrm{mg}$ gallic acid equivalent (GAE)/100 g was determined according to the Folin-Ciocalteu method (Meda et al. 2005). The absorbance of bluecolour complex was measured at $760 \mathrm{~nm}$. Applied reagents were 3,4,5-trihydroxybenzoic acid (Alfa Aesar GmbH \& Co. KG, Karlsruhe, Germany), sodium carbonate and methanol (Scharlab S.L., Spain), Folin-Ciocalteu reagent (VWR International S.A.S., France).

The colour of honey samples was determined by spectrophotometric measurement from a $50 \%$ (w/v) honey solution at $635 \mathrm{~nm}$ (White, 1984). The honeys were classified according to the Pfund scale after conversion of the absorbance values: 
$\mathrm{mm}$ Pfund $=-38.70+371.39 \times \mathrm{A}_{635}$

Sucrose, fructose and glucose contents were determined based on AOAC (1995b) 977.20 methods with HPLC. Applied chemicals were acetonitrile as a mobile phase (VWR International S.A.S., France), sucrose, fructose and glucose standard solution (Alfa Aesar, Thermo Fisher $\mathrm{GmbH}$, Germany). Instruments and equipment used were a chromatograph (Merck Hitachi L6200A, Germany), detector (Merck LaChrom RI Detector L-7490, Germany), column (Phenomenex Luna $5 \mu \mathrm{NH} 2$ 100A, USA), sample clarification kit (PALL A/B Glass $13 \mathrm{~m}$, Sigma-Aldrich Kft., Budapest, Hungary) and syringes (Hamilton MIcroliter $^{\circledR}$ \# 710, Switzerland).

\section{Statistical analysis}

Data were described using general terms (mean, standard deviation, minimum and maximum values), One-Way ANOVA (Linear Discriminant Analysis, LDA, and Least Significant Difference, LSD, tests), Independent-Sample T Tests and Pearson correlations, using SPSS for Windows Version 13 (SPSS Inc. Chicago, Illinois, USA). All analytical determinations were conducted in triplicate.

\section{Results and discussion}

\section{Physicochemical parameters of acacia honey samples}

Based on the statistical analysis (LSD test) the collecting years had no effect on the physicochemical parameters of honey samples. The measured values are summarized in Table 1. Juan-Borrás et al. (2014) measured very similar diastase activity (17.3 DN), electrical conductivity (190 $\mu \mathrm{S} / \mathrm{cm})$ and sugar content $(2.20 \%$ for sucrose, $26.8 \%$ for glucose and $40.2 \%$ for fructose, respectively) in Spanish acacia honeys. Paszkowsky et al. (2014) also determined similar sugar content $(<0.5 \%$ for sucrose, $29.6 \%$ for glucose and $41.2 \%$ for fructose, respectively) and electrical conductivity $(170 \mu \mathrm{S} / \mathrm{cm})$ in Polish acacia honeys. Nayik et al. (2016) reported lower fructose and similar glucose and sucrose content $(35.6 \pm 1.8 \%$, $31.7 \pm 1.4 \%$ and $1.33 \pm 0.09 \%$, respectively) in Kashmir Valley acacia honeys. Turkish acacia honeys showed higher moisture $(20.8 \pm 2.555)$ and proline $(282 \pm 112 \mathrm{mg} / \mathrm{kg})$ contents and electrical conductivity $(300 \pm 250 \mu \mathrm{S} / \mathrm{cm})$, lower fructose and glucose contents $(28.3 \pm 3.2 \%$ and $24.2 \pm 2.8 \%)$ and very similar TPC (16.0 $\pm 2.7 \mathrm{mg} \mathrm{GAE} / 100 \mathrm{~g}$ ) (Can et al. 2015). Anatolian acacia honeys showed lower TPC (9.80 \pm 1.00 and
Table 1 Minimum, maximum, mean and standard deviation values of measured parameters on the acacia honey samples $(\mathrm{n}=44)$

\begin{tabular}{llll}
\hline & Minimum & Maximum & Mean \pm standard deviation \\
\hline Diastase activity $(\mathrm{DN})$ & 15.2 & 20.5 & $18.4 \pm 1.20$ \\
HMF content $(\mathrm{mg} / \mathrm{kg})$ & 0.410 & 5.62 & $2.12 \pm 1.43$ \\
Proline content $(\mathrm{mg} / \mathrm{kg})$ & 204 & 293 & $245 \pm 26$ \\
TPC $(\mathrm{mgGAE} / 100 \mathrm{~g})$ & 10.5 & 22.1 & $16.5 \pm 3.0$ \\
$\mathrm{EC}(\mu \mathrm{S} / \mathrm{cm})$ & 100 & 209 & $141 \pm 34$ \\
Colour & Water white $(<9 \mathrm{~mm})$ & White $(25 \mathrm{~mm})$ & Extra white $(12 \pm 5 \mathrm{~mm})$ \\
$\mathrm{pH}$ & 3.36 & 4.02 & $3.76 \pm 0.21$ \\
Moisture $(\%)$ & 17.0 & 19.8 & $18.4 \pm 0.7$ \\
Sucrose $(\%)$ & $<\mathrm{DL}$ & 2.21 & $0.45 \pm 0.12$ \\
Fructose $(\%)$ & 39.0 & 47.0 & $42.6 \pm 2.53$ \\
$\mathrm{Glucose}(\%)$ & 27.3 & 33.0 & $29.7 \pm 1.65$ \\
As $(\mu \mathrm{g} / \mathrm{kg})$ & 6.65 & 36.5 & $13.8 \pm 6.9$ \\
$\mathrm{~B}(\mathrm{mg} \mathrm{kg})$ & $2.1)$ & 4.14 & $3.05 \pm 0.51$ \\
$\mathrm{Cd}(\mu \mathrm{g} / \mathrm{kg})$ & 2.04 & 0.571 & $0.190 \pm 0.142$ \\
$\mathrm{Cr}(\mu \mathrm{g} / \mathrm{kg})$ & $<\mathrm{DL}$ & $<\mathrm{DL}$ & - \\
$\mathrm{K}(\mathrm{mg} / \mathrm{kg})$ & $<\mathrm{DL}$ & 237 & $185 \pm 30$ \\
Fe $(\mu \mathrm{g} / \mathrm{kg})$ & 132 & 584 & $279 \pm 180$ \\
$\mathrm{Mg}(\mathrm{mg} / \mathrm{kg})$ & 25 & 10.2 & $5.09 \pm 2.48$ \\
$\mathrm{Na}(\mathrm{mg} / \mathrm{kg})$ & 2.48 & 6.40 & $3.44 \pm 1.16$ \\
$\mathrm{P}(\mathrm{mg} / \mathrm{kg})$ & 1.30 & 76.7 & $37.0 \pm 11.8$ \\
$\mathrm{~S}(\mathrm{mg} / \mathrm{kg})$ & 21.7 & 3.37 & $14.5 \pm 3.4$ \\
$\mathrm{Zn}(\mathrm{mg} / \mathrm{kg})$ & 6.40 & & $1.14 \pm 0.96$ \\
\hline & 0.074 & &
\end{tabular}


$12.2 \pm 1.10 \mathrm{mg} \mathrm{GAE} / 100 \mathrm{~g}$ ) and higher Fe concentrations $(1.20 \pm 0.10$ and $1.40 \pm 0.10 \mathrm{mg} / \mathrm{kg}$ ) (Kaygusuz et al. 2016). Very similar B, Cr, Mg $(3.7 \pm 1.1 \mathrm{mg} / \mathrm{kg},<\mathrm{DL}$, $5.0 \pm 8.0 \mathrm{mg} / \mathrm{kg}$ ) contents have been measured in Italian acacia honeys by Bontempo et al. (2015). Calabrian acacia honeys have produced much higher K (719 $\pm 390 \mathrm{mg} / \mathrm{kg})$, $\mathrm{Mg} \quad(70 \pm 27 \mathrm{mg} / \mathrm{kg}), \quad \mathrm{Na} \quad(91 \pm 29 \mathrm{mg} / \mathrm{kg}), \quad \mathrm{Fe}$ $(2.05 \pm 0.72 \mathrm{mg} / \mathrm{kg})$ and $\mathrm{Cr}(0.68 \pm 0.25 \mathrm{mg} / \mathrm{kg})$ concentrations (Di Bella et al. 2015).

In Hungary there exists a Regulation of Codex Alimentarius Hungaricus 2-100 Directive (2009), for "Honey with distinctive quality indication". The specific requirements in this Regulation are: moisture content no more than $18.5 \%$, sucrose content no more than $6 \%$, HMF content no more than $20 \mathrm{mg} / \mathrm{kg}$, ratio of glucose-fructose is 1.5-1.8, proline content is a minimum of $200 \mathrm{mg} / \mathrm{kg}$, diastase activity is a minimum of $10 \mathrm{DN}$ and the acacia pollen rate is $\min$. $15 \%$. From the examined 44 samples, 21 samples corresponded to these requirements.

Based on Pearson correlation coefficient (CC value), there were significant positive relationships at the 0.01 level between $\mathrm{EC}$ and $\mathrm{K}$ content $(\mathrm{CC}=0.948), \mathrm{EC}$ and $\mathrm{Mg}$ content $(\mathrm{CC}=0.637), \mathrm{pH}$ and As content $(\mathrm{CC}=-0.557)$, $\mathrm{K}$ and $\mathrm{Mg}$ content $(\mathrm{CC}=0.576), \mathrm{S}$ and $\mathrm{Mg}$ content $(\mathrm{CC}=0.672)$, fructose and glucose content $(\mathrm{CC}=0.971)$. Lower CC values of between 0.4 and 0.5 (but still significant at the 0.01 level) were observed in case of EC and $\mathrm{P}$ (0.439), EC and $\mathrm{Zn}(0.475), \mathrm{pH}$ and TPC (- 0.449), proline content and TPC $(0.421)$, proline and $\mathrm{K}$ content (0.405), proline and $\mathrm{P}$ content $(0.470)$, proline and $\mathrm{S}$ content (0.417), proline and Mg content (0.453), TPC and $\mathrm{P}$ content (0.434), $\mathrm{K}$ and $\mathrm{P}$ content $(0.477), \mathrm{K}$ and $\mathrm{Fe}$ content (0.411), $\mathrm{K}$ and $\mathrm{Zn}$ content (0.427), $\mathrm{K}$ and $\mathrm{S}$ content (0.408), $\mathrm{Na}$ and $\mathrm{S}$ content (0.428), $\mathrm{S}$ and $\mathrm{Zn}$ content (0.441), Fe and B content (0.428).

\section{The effect of centrifuging and filtration}

After centrifuging and filtration the moisture content of samples increased (Table 2), which was probably due to hygroscopic absorption of moisture by the honeys following removal of the wax capping from the cells. The sugar content, diastase activity, HMF content and $\mathrm{pH}$ value did not change. Proline contents were reduced by $24 \%$ in samples 1 and 2 and $17.5 \%$ in sample 3. TPC was reduced in all three samples, by on average $40 \%$. The reduction in proline and TPC contents can be explained by the filtration reducing the pollen content of samples, which had very high proline $(11,711 \pm 152 \mathrm{mg} / \mathrm{kg})$ and TPC $(484 \pm 6 \mathrm{mg}$ gallic acid equivalent [GAE]/100 g) contents. The reduction in electrical conductivity was about $80 \mu \mathrm{S} / \mathrm{cm}$, probably due to the correlation of this parameter with the mineral content that decreased after the centrifuging and filtration. Before treatment samples were a white colour, but after centrifuging and filtration they were extra white. The reduction in macroelement concentration was significant, most importantly in potassium, sodium and phosphorus.

The main reason for these changes appears to be the presence of different extraneous material in the honey (e.g.

Table 2 Chemical parameters of acacia honey before and after centrifuging and filtration

\begin{tabular}{|c|c|c|c|c|c|c|}
\hline & \multicolumn{2}{|l|}{ Sample 1} & \multicolumn{2}{|l|}{ Sample 2} & \multicolumn{2}{|l|}{ Sample 3} \\
\hline & Before & After & Before & After & Before & After \\
\hline Proline content (mg/kg) & $374 \pm 3.6$ & $284 \pm 3.0$ & $287 \pm 4$ & $218 \pm 3$ & $229 \pm 1$ & $189 \pm 2$ \\
\hline TPC (mgGAE/100 g) & $32.3 \pm 0.1$ & $20.5 \pm 0.1$ & $24.9 \pm 0.3$ & $14.8 \pm 0.2$ & $25.1 \pm 0.1$ & $14.9 \pm 0.1$ \\
\hline $\mathrm{EC}(\mu \mathrm{S} / \mathrm{cm})$ & $312 \pm 1$ & $224 \pm 4$ & $231 \pm 3$ & $157 \pm 3$ & $234 \pm 4$ & $153 \pm 2$ \\
\hline Colour (mm) & $33.0 \pm 1.0$ & $12.0 \pm 1$ & $28.0 \pm 1.5$ & $17.0 \pm 1.5$ & $27.0 \pm 1.0$ & $12.0 \pm 1$ \\
\hline Moisture (\%) & $16.0 \pm 0.01$ & $16.5 \pm 0.02$ & $16.7 \pm 0.1$ & $18.4 \pm 0.1$ & $16.0 \pm 0.1$ & $17.5 \pm 0.1$ \\
\hline As $(\mu \mathrm{g} / \mathrm{kg})$ & $22.7 \pm 0.1$ & $20.9 \pm 1.0$ & $11.0 \pm 0.2$ & $10.8 \pm 0.5$ & $13.6 \pm 0.2$ & $13.4 \pm 0.5$ \\
\hline $\mathrm{B}(\mathrm{mg} / \mathrm{kg})$ & $11.3 \pm 0.1$ & $5.39 \pm 0.0$ & $3.59 \pm 0.02$ & $2.94 \pm 0.0$ & $3.63 \pm 0.16$ & $2.85 \pm 0.19$ \\
\hline $\mathrm{Cd}(\mu \mathrm{g} / \mathrm{kg})$ & $<\mathrm{LOD}$ & $<\mathrm{LOD}$ & $<\mathrm{LOD}$ & $<$ LOD & $<\mathrm{LOD}$ & $<\mathrm{LOD}$ \\
\hline $\mathrm{Cr}(\mu \mathrm{g} / \mathrm{kg})$ & $4.79 \pm 0.02$ & $<\mathrm{LOD}$ & $<\mathrm{LOD}$ & $<$ LOD & $<$ LOD & $<\mathrm{LOD}$ \\
\hline $\mathrm{Fe}(\mu \mathrm{g} / \mathrm{kg})$ & $774 \pm 2$ & $590 \pm 2$ & $598 \pm 8$ & $503 \pm 9$ & $749 \pm 15$ & $627 \pm 7$ \\
\hline $\mathrm{K}(\mathrm{mg} / \mathrm{kg})$ & $523 \pm 1$ & $367 \pm 2$ & $359 \pm 1.7$ & $221 \pm 1.7$ & $372 \pm 1$ & $208 \pm 1$ \\
\hline $\mathrm{Mg}(\mathrm{mg} / \mathrm{kg})$ & $8.14 \pm 0.45$ & $6.56 \pm 0.15$ & $4.42 \pm 0.20$ & $1.81 \pm 0.13$ & $5.61 \pm 0.09$ & $1.37 \pm 0.22$ \\
\hline $\mathrm{Na}(\mathrm{mg} / \mathrm{kg})$ & $13.8 \pm 1.5$ & $4.74 \pm 0.11$ & $12.3 \pm 0.1$ & $3.43 \pm 0.02$ & $9.85 \pm 0.04$ & $2.36 \pm 0.05$ \\
\hline $\mathrm{P}(\mathrm{mg} / \mathrm{kg})$ & $55.9 \pm 1.2$ & $37.6 \pm 1.3$ & $61.2 \pm 0.85$ & $46.3 \pm 0.2$ & $72.5 \pm 0.4$ & $44.7 \pm 1.2$ \\
\hline $\mathrm{S}(\mathrm{mg} / \mathrm{kg})$ & $34.2 \pm 0.8$ & $26.8 \pm 1.4$ & $32.8 \pm 0.6$ & $23.3 \pm 0.6$ & $31.6 \pm 1.3$ & $22.7 \pm 1.4$ \\
\hline $\mathrm{Zn}(\mu \mathrm{g} / \mathrm{kg})$ & $1014 \pm 11$ & $783 \pm 9$ & $723 \pm 11$ & $448 \pm 5$ & $891 \pm 3$ & $575 \pm 7$ \\
\hline
\end{tabular}

$L O D$ limit of detection 
wax capping, comb and bee pieces, pollens). After centrifuging and filtration these matters were removed by gravity and the filtering. In the case of Sample 1 (Table 2) the micro and macro element contents of comb and wax capping were determined. Both contained high concentrations of $\mathrm{K}$, so this was much reduced after centrifuging and filtration $(626 \pm 15.1 \mathrm{mg} \mathrm{K} / \mathrm{kg}$ in comb and $1018 \pm 32.1 \mathrm{mg} \mathrm{K} / \mathrm{kg}$ in wax capping). The reduction in phosphorus concentration was about $18 \mathrm{mg} / \mathrm{kg}$, with $104 \pm 1.54 \mathrm{mg} / \mathrm{kg}$ in the comb and $118 \pm 2.16 \mathrm{mg} / \mathrm{kg}$ in the wax capping. The changes in boron and sodium concentrations were also important, but the content of these elements were not much increased in the comb $(14.3 \pm 0.34 \mathrm{mg} / \mathrm{kg}$ for boron and $19.0 \pm 0.46 \mathrm{mg} / \mathrm{kg}$ for sodium) or the wax capping $(14.7 \pm 0.29 \mathrm{mg} / \mathrm{kg}$ for boron and $13.8 \pm 0.32 \mathrm{mg} / \mathrm{kg}$ for sodium). Sulphur contents of comb and wax capping was similar in both $(73.3 \pm 1.32$ and $71.6 \pm 1.32 \mathrm{mg} / \mathrm{kg}$ in comb and wax capping, respectively). The change in magnesium concentration was negligible, although the content in comb $(27.7 \pm 3.36 \mathrm{mg} /$ $\mathrm{kg})$ and wax capping $(32.3 \pm 1.12 \mathrm{mg} / \mathrm{kg})$ was high.

Sample 1 did not contain cadmium in either the comb or the wax capping. Before the centrifuging Sample 1 contained chromium, however afterwards the concentration of these elements was under the DL. The comb and wax capping contained chromium $(35.6 \pm 4.05 \mu \mathrm{g} / \mathrm{kg}$ and $62.1 \pm 4.14 \mu \mathrm{g} / \mathrm{kg}$ ), thus these elements were measurable in this sample before the centrifuging. After treatment these elements were removed from the honey. The arsenic content of Sample 1 came from the nectar, because this toxic element was not measurable in the comb or wax capping and its concentration did not change after the centrifuging. Very high iron and zinc concentrations were measured in the comb $(10,110 \pm 216 \mu \mathrm{g} / \mathrm{kg}$ and $12,028 \pm 370 \mu \mathrm{g} / \mathrm{kg}$ ) and wax capping $(12,282 \pm 49.9 \mu \mathrm{g} / \mathrm{kg}$ and $10,924 \pm 118 \mu \mathrm{g} / \mathrm{kg})$ that influenced the iron and zinc content of Sample 1. Another reason for the changed concentrations was the increase in moisture content of samples.

\section{The effect of heating}

The results of thermal heating on the physicochemical properties of honey are presented in Table 3. Diastase activity was reduced by only $5 \mathrm{DN}$ at $80^{\circ} \mathrm{C}$, which was probably because of the freshness of sample and because the initial activity was very high. The value of this parameter conformed to the EU Council Directive 2001/110/EC. Tosi et al. (2008) found that heating caused a much greater reduction in diastase activity (from $25.8 \pm 0.9$ to $14.1 \pm \mathrm{DN}$ ) in six honey samples. Heating to $40{ }^{\circ} \mathrm{C}$ and $50{ }^{\circ} \mathrm{C}$ did not affect the HMF content, but the higher temperatures increased it. The values still did not exceed the limits of the EU Directive due to the initial low values. Singh and Bath (1997) reported that heating to $65{ }^{\circ} \mathrm{C}$ had a similar effect on the HMF content of their examined honey samples. In another study, heating to $70{ }^{\circ} \mathrm{C}$ for 60 min resulted in an increase in HMF content of sunflower and eucalyptus honeys; however these changes were not so pronounced as in our samples (Bath and Singh 1999). Singh and Bath (1998) reported that the honey with low $\mathrm{pH}$ value produced more HMF under heating. Our result confirmed this claim because our sample had a low $\mathrm{pH}$ value and the increase of HMF content was significant; even though the $\mathrm{pH}$ value did not change.

Heating reduced proline content, particularly at $70{ }^{\circ} \mathrm{C}$ and $80^{\circ} \mathrm{C}$, in which it was reduced by 18 and $31 \mathrm{mg} / \mathrm{kg}$, respectively. Based on our previous study (Czipa et al. 2012), the reduction in this parameter is more obvious in floral samples, in which proline content (which was very high in the unheated sample, $832 \mathrm{mg} / \mathrm{kg}$ ) was reduced by 38,42 and $44 \%$ at 50,60 and $80^{\circ} \mathrm{C}$ when heated for $20 \mathrm{~min}$. Heating also has an effect on the colour of honey samples that is due to the increase in HMF content. The colour value was increased by $50 \%$, therefore the extra white colour became white. Heating had no significant effect on TPC content, electrical conductivity, $\mathrm{pH}$, moisture content and element contents.

Table 3 The effect of heating to $40-80{ }^{\circ} \mathrm{C}$ for $60 \mathrm{~min}$ on the chemical parameters of acacia honeys

\begin{tabular}{lcccccc}
\hline & Unheated & $40{ }^{\circ} \mathrm{C}$ & $50{ }^{\circ} \mathrm{C}$ & $60{ }^{\circ} \mathrm{C}$ & $70{ }^{\circ} \mathrm{C}$ & $80{ }^{\circ} \mathrm{C}$ \\
\hline Diastase activity $(\mathrm{DN})$ & $25.8 \pm 0.3$ & $25.4 \pm 0.0$ & $24.9 \pm 0.1$ & $24.6 \pm 0.2$ & $22.5 \pm 0.1$ & $20.7 \pm 0.1$ \\
HMF content $(\mathrm{mg} / \mathrm{kg})$ & $0.31 \pm 0.01$ & $0.29 \pm 0.02$ & $0.36 \pm 0.05$ & $4.45 \pm 0.12$ & $7.37 \pm 0.26$ & $10.2 \pm 1.1$ \\
Proline content $(\mathrm{mg} / \mathrm{kg})$ & $284 \pm 3$ & $280 \pm 1$ & $275 \pm 1$ & $272 \pm 1$ & $264 \pm 1$ \\
TPC $(\mathrm{mgGAE} / 100 \mathrm{~g})$ & $20.5 \pm 0.2$ & $20.1 \pm 0.8$ & $18.8 \pm 0.0$ & $18.9 \pm 0.2$ & $17.8 \pm 0.1$ & $253 \pm 1$ \\
$\mathrm{EC}(\mu \mathrm{S} / \mathrm{cm})$ & $224 \pm 3$ & $224 \pm 4$ & $219 \pm 4$ & $218 \pm 2$ & $219 \pm 1$ \\
$\mathrm{pH}$ & $3.91 \pm 0.01$ & $3.99 \pm 0.03$ & $3.98 \pm 0.03$ & $4.02 \pm 0.02$ & $4.06 \pm 0.03$ & $3.96 \pm 0.02$ \\
Moisture $(\%)$ & $16.5 \pm 0.1$ & $16.5 \pm 0.10$ & $16.6 \pm 0.1$ & $16.6 \pm 0.1$ & $16.7 \pm 0.2$ \\
Colour $(\mathrm{mm})$ & $12.0 \pm 0.2$ & $15.7 \pm 0.1$ & $18.2 \pm 0.3$ & $20.3 \pm 0.1$ & $22.1 \pm 0.2$ \\
\hline
\end{tabular}




\section{The effect of sugar syrups}

When the honey with added sugar products was tested for physicochemical properties, diastase activities and HMF contents were very low in every sample and GS did not show the presence of diastase (Table 4). Proline contents were also low, except GS where the value was very high. Low TPC content was measured in GS and FGS, but the two IS samples showed a high content. Low electrical conductivity was determined in all four samples. The highest moisture content was determined in the ISE product followed by FGS, ISA and GS. GS and FGS showed higher $\mathrm{pH}$ values than ISA and ISE. The highest sucrose content was measured in ISA, but the sucrose content of ISE was very low. Fructose content was low in GS and ISA and the other two sugar product showed similar high values. Glucose content was about $30 \%$ in GS, FGS and ISE but ISA showed a much lower value. $\mathrm{B}, \mathrm{Cd}, \mathrm{Cr}, \mathrm{Fe}, \mathrm{K}, \mathrm{Mg}$, $\mathrm{Na}$ and $\mathrm{Zn}$ concentrations were under DL in GS and $\mathrm{Cr}, \mathrm{K}$, $\mathrm{Mg}$ and $\mathrm{Zn}$ content were also under DL in FGS. As and $\mathrm{S}$ contents were higher in the commercial sugar products, GS and FGS, but the other element content was higher in other two sugar samples.
The results of original acacia and adulterated honey samples are shown in Table 5. Due to the low diastase activity of sugar products the adulterated samples showed lower DN values than the original acacia honey, even though the diastase activities did not decrease under the prescribed value. However if the original acacia sample has lower diastase activity these sugar products can diminish the diastase activity to less than $8 \mathrm{DN}$. The proline content of GS was particularly high and due to this fact the adulterated samples with this sugar product showed high proline concentration. However the value of this parameter was very low in FGS, ISA and ISE; therefore the proline content of adulterated samples with these sugar products showed low concentration that was at the limit value of the EU Directive at levels of 60:40. For TPC there was no change in adulterated acacia honey samples with ISA and ISE because of their relative high TPC. In H:GS $=60: 40$ and H:FGS $=60: 40$ the diminution was about $35 \%$ and 23\%. The EU Directive does not regulate the limits of TPC, so attempts to use this value to prove adulteration are not probable. Lower EC was measured in commercial sugar products than in ISA and ISE, hence there was a reduction in adulterated samples. Electrical conductivity is very low in acacia honey due to the low potassium content (Czipa
Table 4 Physicochemical parameters of sugar products

\begin{tabular}{|c|c|c|c|c|}
\hline \multirow[t]{2}{*}{ Parameters } & \multicolumn{4}{|l|}{ Adulterants } \\
\hline & GS & FGS & ISA & ISE \\
\hline Diastase activity (DN) & $<\mathrm{DL}$ & $2.20 \pm 0.03$ & $1.61 \pm 0.04$ & $1.92 \pm 0.02$ \\
\hline HMF content $(\mathrm{mg} / \mathrm{kg})$ & $0.82 \pm 0.02$ & $1.12 \pm 0.05$ & $0.51 \pm 0.02$ & $0.56 \pm 0.02$ \\
\hline Proline content $(\mathrm{mg} / \mathrm{kg})$ & $236 \pm 11$ & $12.0 \pm 0.0$ & $33.0 \pm 0.58$ & $39.2 \pm 1.3$ \\
\hline TPC (mgGAE/100 g) & $2.19 \pm 0.02$ & $8.29 \pm 0.11$ & $24.4 \pm 1.0$ & $28.0 \pm 1.5$ \\
\hline $\mathrm{EC}(\mu \mathrm{S} / \mathrm{cm})$ & $7.49 \pm 0.12$ & $11.0 \pm 0.2$ & $39.1 \pm 0.00$ & $65.2 \pm 0.00$ \\
\hline Colour (mm) & $<\mathrm{DL}$ & $<\mathrm{DL}$ & $7.4 \pm 0.5$ & $6.1 \pm 0.2$ \\
\hline $\mathrm{pH}$ & $5.57 \pm 0.12$ & $5.26 \pm 0.23$ & $4.26 \pm 0.01$ & $4.47 \pm 0.08$ \\
\hline Moisture (\%) & $14.9 \pm 0.1$ & $20.7 \pm 0.0$ & $16.2 \pm 0.7$ & $25.4 \pm 0.3$ \\
\hline Sucrose $(\%)$ & $6.42 \pm 0.05$ & $4.45 \pm 0.05$ & $69.6 \pm 0.6$ & $0.34 \pm 0.04$ \\
\hline Fructose $(\%)$ & $7.63 \pm 0.03$ & $38.1 \pm 1.0$ & $10.6 \pm 0.26$ & $34.9 \pm 0.3$ \\
\hline Glucose $(\%)$ & $30.6 \pm 0.20$ & $30.4 \pm 0.3$ & $9.32 \pm 0.06$ & $33.7 \pm 0.3$ \\
\hline As $(\mu \mathrm{g} / \mathrm{kg})$ & $42.7 \pm 0.2$ & $35.8 \pm 0.1$ & $4.48 \pm 0.06$ & $4.62 \pm 0.12$ \\
\hline B (mg/kg) & $<\mathrm{DL}$ & $<\mathrm{DL}$ & $0.37 \pm 0.01$ & $0.17 \pm 0.02$ \\
\hline $\mathrm{Cd}(\mu \mathrm{g} / \mathrm{kg})$ & $<\mathrm{DL}$ & $1.02 \pm 0.09$ & $0.66 \pm 0.6$ & $0.74 \pm 0.03$ \\
\hline $\mathrm{Cr}(\mu \mathrm{g} / \mathrm{kg})$ & $<\mathrm{DL}$ & $<\mathrm{DL}$ & $<\mathrm{DL}$ & $<\mathrm{DL}$ \\
\hline $\mathrm{Fe}(\mu \mathrm{g} / \mathrm{kg})$ & $<\mathrm{DL}$ & $26.7 \pm 0.7$ & $50.4 \pm 2.3$ & $86.2 \pm 0.9$ \\
\hline $\mathrm{K}(\mathrm{mg} / \mathrm{kg})$ & $<\mathrm{DL}$ & $<\mathrm{DL}$ & $26.5 \pm 1.1$ & $24.7 \pm 0.9$ \\
\hline $\mathrm{Mg}(\mathrm{mg} / \mathrm{kg})$ & $<\mathrm{DL}$ & $<\mathrm{DL}$ & $0.77 \pm 0.03$ & $0.38 \pm 0.01$ \\
\hline $\mathrm{Na}(\mathrm{mg} / \mathrm{kg})$ & $<\mathrm{DL}$ & $1.09 \pm 0.03$ & $13.5 \pm 0.4$ & $51.5 \pm 0.6$ \\
\hline $\mathrm{P}(\mathrm{mg} / \mathrm{kg})$ & $0.21 \pm 0.01$ & $1.80 \pm 0.02$ & $<\mathrm{LOD}$ & $1.36 \pm 0.02$ \\
\hline $\mathrm{S}(\mathrm{mg} / \mathrm{kg})$ & $13.6 \pm 0.2$ & $16.8 \pm 0.5$ & $6.42 \pm 0.25$ & $6.38 \pm 0.13$ \\
\hline $\mathrm{Zn}(\mu \mathrm{g} / \mathrm{kg})$ & $<\mathrm{DL}$ & $<\mathrm{DL}$ & $87.0 \pm 1.1$ & $134 \pm 1$ \\
\hline
\end{tabular}

$G S$ glucose syrup, $F G S$ fructose-glucose syrup, ISA invert sugar 1, ISE invert sugar 2 
Table 5 Physicochemical parameters of original and adulterated acacia honey samples

\begin{tabular}{|c|c|c|c|c|c|c|c|c|c|}
\hline & \multirow{2}{*}{$\begin{array}{l}\text { Original } \\
\text { honey }\end{array}$} & \multicolumn{2}{|l|}{ Honey:GS } & \multicolumn{2}{|l|}{ Honey:FGS } & \multicolumn{2}{|l|}{ Honey:ISA } & \multicolumn{2}{|l|}{ Honey:ISE } \\
\hline & & $70: 30$ & $60: 40$ & $70: 30$ & $60: 40$ & $70: 30$ & $60: 40$ & $70: 30$ & $60: 40$ \\
\hline $\begin{array}{l}\text { Diastase } \\
\text { activity } \\
\text { (DN) }\end{array}$ & $25.8 \pm 0.3$ & $17.5 \pm 0.1$ & $15.4 \pm 1.0$ & $19.8 \pm 0.1$ & $16.9 \pm 0.2$ & $19.1 \pm 0.4$ & $15.9 \pm 0.4$ & $18.8 \pm 0.4$ & $16.1 \pm 0.1$ \\
\hline $\begin{array}{l}\text { HMF } \\
\text { content } \\
(\mathrm{mg} / \mathrm{kg})\end{array}$ & $0.51 \pm 0.02$ & $.53 \pm 0.01$ & $0.55 \pm 0.02$ & $0.58 \pm 0.01$ & $0.59 \pm 0.01$ & $0.50 \pm 0.01$ & $0.50 \pm 0.02$ & $0.51 \pm 0.02$ & $0.49 \pm 0.01$ \\
\hline $\begin{array}{l}\text { Proline } \\
\text { content } \\
(\mathrm{mg} / \mathrm{kg})\end{array}$ & $284 \pm 5$ & $274 \pm 4$ & $260 \pm 4$ & $209 \pm 7$ & $179 \pm 3$ & $199 \pm 9$ & $181 \pm 7$ & $214 \pm 6$ & $184 \pm 2$ \\
\hline $\begin{array}{l}\text { TPC } \\
\text { (mgGAE/ } \\
100 \mathrm{~g})\end{array}$ & $20.5 \pm 0.2$ & $14.9 \pm 0.1$ & $13.3 \pm 0.1$ & $16.9 \pm 0.1$ & $15.7 \pm 0.0$ & $21.9 \pm 1.1$ & $22.0 \pm 0.1$ & $22.9 \pm 1.1$ & $23.3 \pm 1.0$ \\
\hline $\begin{array}{c}\mathrm{EC}(\mu \mathrm{S} / \\
\mathrm{cm})\end{array}$ & $224 \pm 3$ & $161 \pm 3$ & $137 \pm 2$ & $159 \pm 3$ & $140 \pm 3$ & $159 \pm 3$ & $142 \pm 3$ & $174 \pm 7$ & $153 \pm 3$ \\
\hline $\begin{array}{r}\text { Colour } \\
(\mathrm{mm})\end{array}$ & $12.0 \pm 0.2$ & $5.3 \pm 0.5$ & $3.99 \pm 0.10$ & $3.99 \pm 0.03$ & $1.09 \pm 0.08$ & $8.42 \pm 0.15$ & $7.11 \pm 0.08$ & $7.93 \pm 0.11$ & $7.02 \pm 0.10$ \\
\hline $\mathrm{pH}$ & $3.91 \pm 0.01$ & $4.48 \pm 0.01$ & $4.63 \pm 0.01$ & $4.03 \pm 0.01$ & $4.52 \pm 0.02$ & $4.04 \pm 0.17$ & $4.10 \pm 0.06$ & $4.10 \pm 0.07$ & $4.16 \pm 0.11$ \\
\hline $\begin{array}{l}\text { Moisture } \\
(\%)\end{array}$ & $16.5 \pm 0.1$ & $16.2 \pm 0.1$ & $15.9 \pm 0.1$ & $17.9 \pm 0.1$ & $18.1 \pm 0.3$ & $16.4 \pm 0.4$ & $16.4 \pm 0.4$ & $19.5 \pm 0.1$ & $20.2 \pm 0.2$ \\
\hline $\begin{array}{c}\text { Sucrose } \\
(\%)\end{array}$ & $<\mathrm{DL}$ & $2.12 \pm 0.41$ & $2.73 \pm 0.12$ & $1.41 \pm 0.11$ & $1.82 \pm 0.21$ & $18.7 \pm 0.4$ & $25.8 \pm 1.1$ & $<\mathrm{DL}$ & $<\mathrm{DL}$ \\
\hline $\begin{array}{c}\text { Fructose } \\
(\%)\end{array}$ & $47.3 \pm 1.1$ & $36.2 \pm 1.5$ & $30.3 \pm 1.1$ & $44.2 \pm 1.3$ & $43.8 \pm 1.8$ & $35.4 \pm 1.2$ & $31.8 \pm 0.2$ & $43.4 \pm 1.4$ & $42.9 \pm 1.1$ \\
\hline $\begin{array}{c}\text { Glucose } \\
(\%)\end{array}$ & $32.7 \pm 1.3$ & $32.5 \pm 1.0$ & $32.4 \pm 1.2$ & $32.4 \pm 1.1$ & $32.4 \pm 1.4$ & $24.1 \pm 0.2$ & $22.6 \pm 1.6$ & $33.5 \pm 1.1$ & $33.6 \pm 0.4$ \\
\hline As $(\mu \mathrm{g} / \mathrm{kg})$ & $38.2 \pm 1.2$ & $38.2 \pm 1.3$ & $40.3 \pm 1.3$ & $37.4 \pm 1.5$ & $37.3 \pm 2.1$ & $27.3 \pm 1.3$ & $25.1 \pm 0.8$ & $29.2 \pm 0.7$ & $22.3 \pm 0.9$ \\
\hline $\mathrm{B}(\mathrm{mg} / \mathrm{kg})$ & $5.39 \pm 0.16$ & $3.82 \pm 0.12$ & $3.05 \pm 0.12$ & $3.82 \pm 0.25$ & $3.13 \pm 0.04$ & $3.91 \pm 0.51$ & $3.42 \pm 0.04$ & $3.74 \pm 0.12$ & $3.25 \pm 0.05$ \\
\hline $\mathrm{Cd}(\mu \mathrm{g} / \mathrm{kg})$ & $1.03 \pm 0.12$ & $0.61 \pm 0.02$ & $0.62 \pm 0.03$ & $1.03 \pm 0.02$ & $1.02 \pm 0.09$ & $1.01 \pm 0.03$ & $0.83 \pm 0.05$ & $0.98 \pm 0.02$ & $0.92 \pm 0.05$ \\
\hline $\mathrm{Cr}(\mu \mathrm{g} / \mathrm{kg})$ & $<\mathrm{DL}$ & $<\mathrm{DL}$ & $<\mathrm{DL}$ & $<\mathrm{DL}$ & $<\mathrm{DL}$ & $<\mathrm{DL}$ & $<\mathrm{DL}$ & $<\mathrm{DL}$ & $<\mathrm{DL}$ \\
\hline $\mathrm{Fe}(\mu \mathrm{g} / \mathrm{kg})$ & $691 \pm 15$ & $482 \pm 12$ & $429 \pm 9$ & $501 \pm 8$ & $420 \pm 12$ & $502 \pm 4$ & $431 \pm 8$ & $508 \pm 5$ & $442 \pm 4$ \\
\hline $\mathrm{K}(\mathrm{mg} / \mathrm{kg})$ & $267 \pm 3$ & $182 \pm 3$ & $158 \pm 5$ & $193 \pm 3$ & $158 \pm 4$ & $198 \pm 3$ & $164 \pm 5$ & $201 \pm 7$ & $172 \pm 9$ \\
\hline $\begin{array}{l}\mathrm{Mg}(\mathrm{mg} / \\
\mathrm{kg})\end{array}$ & $6.22 \pm 0.15$ & $4.48 \pm 0.05$ & $3.79 \pm 0.1$ & $4.38 \pm 0.34$ & $3.73 \pm 0.2$ & $4.69 \pm 0.14$ & $4.13 \pm 0.11$ & $4.39 \pm 0.08$ & $3.98 \pm 0.14$ \\
\hline $\mathrm{Na}(\mathrm{mg} / \mathrm{kg})$ & $4.74 \pm 0.11$ & $3.35 \pm 0.02$ & $2.86 \pm 0.07$ & $3.65 \pm 0.56$ & $3.26 \pm 0.06$ & $7.51 \pm 0.21$ & $8.41 \pm 0.05$ & $20.1 \pm 0.11$ & $22.3 \pm 0.01$ \\
\hline $\mathrm{P}(\mathrm{mg} / \mathrm{kg})$ & $37.6 \pm 1.4$ & $26.8 \pm 0.1$ & $22.7 \pm 0.07$ & $26.1 \pm 0.6$ & $23.6 \pm 0.37$ & $26.1 \pm 0.2$ & $22.4 \pm 0.4$ & $26.2 \pm 1.1$ & $22.9 \pm 0.7$ \\
\hline $\mathrm{S}(\mathrm{mg} / \mathrm{kg})$ & $20.8 \pm 1.5$ & $18.2 \pm 0.1$ & $18.0 \pm 0.1$ & $18.9 \pm 1.2$ & $19.0 \pm 0.1$ & $16.3 \pm 0.1$ & $15.2 \pm 0.3$ & $16.5 \pm 0.7$ & $15.2 \pm 0.1$ \\
\hline $\mathrm{Zn}(\mu \mathrm{g} / \mathrm{kg})$ & $864 \pm 14$ & $612 \pm 12$ & $503 \pm 20$ & $598 \pm 11$ & $509 \pm 13$ & $611 \pm 7$ & $547 \pm 3$ & $664 \pm 5$ & $565 \pm 8$ \\
\hline
\end{tabular}

and Kovács 2014), so this parameter is probably not able to filter out the adulterated acacia honeys. When contaminated with sugar products the change of colour was significant, from extra white to water white. The $\mathrm{pH}$ values of sugar products were higher than that of the original acacia sample; therefore the $\mathrm{pH}$ value was also higher in the adulterated samples. The moisture content was lower in the acacia samples adulterated with GS and ISA due to the low moisture content of these two sugar products. In the case of the other two sugar products the moisture content was higher, therefore the adulterated acacia samples with FGS and ISE showed increased water content. In the case of the
Honey:FGS mixture in the ratio 60:40, the moisture content was higher than the limit of the EU Directive. The sucrose content of the original acacia honey was under the DL $(0.2 \%)$ and mixing with the sugar products increased the sucrose content in adulterated samples. The highest increase was detected in samples adulterated with ISA, in which case the values exceeded $10 \%$, which is greater than the EU Directive. In the case of samples adulterated with GS and FGS, the sucrose content was higher than in the original samples but it was not higher than the maximum limit of the EU Directive. The sucrose content of honeys adulterated with ISE was under the DL. Significant fructose 
Table 6 Physicochemical parameters of acacia honeys after 2 years storage

\begin{tabular}{|c|c|c|c|c|c|c|}
\hline & Diastase activity (DN) & HMF content $(\mathrm{mg} / \mathrm{kg})$ & Proline content $(\mathrm{mg} / \mathrm{kg})$ & TPC (mgGAE/100 g) & Sucrose $(\%)$ & Color $(\mathrm{mm})$ \\
\hline \multicolumn{7}{|c|}{ Sample 1} \\
\hline 2015 & $17.1 \pm 0.3$ & $1.05 \pm 0.01$ & $242 \pm 5$ & $20.3 \pm 0.2$ & $0.52 \pm 0.02$ & Water white \\
\hline 2017 & $14.3 \pm 0.2$ & $12.1 \pm 0.1$ & $230 \pm 4$ & $25.3 \pm 0.1$ & $0.78 \pm 0.01$ & Extra white \\
\hline \multicolumn{7}{|c|}{ Sample 2} \\
\hline 2015 & $16.8 \pm 0.3$ & $4.27 \pm 0.51$ & $290 \pm 2$ & $19.0 \pm 0.2$ & $1.13 \pm 0.03$ & Extra white \\
\hline 2017 & $14.2 \pm 0.3$ & $20.2 \pm 0.8$ & $261 \pm 3$ & $24.4 \pm 0.1$ & $1.56 \pm 0.01$ & White \\
\hline \multicolumn{7}{|c|}{ Sample 3} \\
\hline 2015 & $15.7 \pm 0.1$ & $0.451 \pm 0.012$ & $280 \pm 4$ & $19.1 \pm 0.2$ & $0.69 \pm 0.03$ & Water white \\
\hline 2017 & $14.0 \pm 0.2$ & $9.41 \pm 0.12$ & $263 \pm 2$ & $23.5 \pm 0.2$ & $0.98 \pm 0.02$ & Water white \\
\hline \multicolumn{7}{|c|}{ Sample 4} \\
\hline 2015 & $20.1 \pm 0.0$ & $1.80 \pm 0.05$ & $244 \pm 3$ & $17.3 \pm 0.1$ & $1.69 \pm 0.12$ & Water white \\
\hline 2017 & $16.7 \pm 0.1$ & $13.4 \pm 0.2$ & $219 \pm 4$ & $21.5 \pm 0.3$ & $2.03 \pm 0.19$ & Extra white \\
\hline \multicolumn{7}{|c|}{ Sample 5} \\
\hline 2015 & $19.3 \pm 0.1$ & $1.87 \pm 0.10$ & $222 \pm 3$ & $16.2 \pm 0.2$ & $0.88 \pm 0.03$ & Water white \\
\hline 2017 & $16.1 \pm 0.1$ & $12.9 \pm 0.7$ & $196 \pm 4$ & $20.2 \pm 0.1$ & $1.23 \pm 0.11$ & Extra white \\
\hline
\end{tabular}

reduction was measured in samples adulterated with GS and ISA. Glucose content did not change except in honey adulterated with ISA, in which case it reduced by about $10 \%$.

Since $\mathrm{B}, \mathrm{Cd}, \mathrm{Cr}, \mathrm{Fe}, \mathrm{K}, \mathrm{Mg}, \mathrm{Na}$ and $\mathrm{Zn}$ were not detected in GS, the concentration of these elements in adulterated acacia honey samples with a 60:40 ratio was lower by about $40 \%$ than in the original sample, similarly with the $\mathrm{B}, \mathrm{K}, \mathrm{Mg}$ and $\mathrm{Zn}$ content of samples adulterated with FGS. Arsenic content was not changed in acacia honey samples adulterated with either GS or FGS; however the concentration of this toxic element decreased in samples adulterated with ISA and ISE. Cadmium was detected in both original acacia honey samples and sugar productsexcept in GS - and these concentrations were similar, thus adulteration did not bring about an important change. In the case of other elements some reduction was observed in adulterated acacia samples.

\section{The effect of collection year and location}

After LDA and LSD tests, it was concluded that there was no statistically verifiable difference due to collecting years. However, examining the collecting area (Eastern Hungary and Western Hungary), there were statistically verified differences in $\mathrm{Na}, \mathrm{Fe}$ and As concentrations, according to an Independent-Samples $\mathrm{T}$ Test. Acacia honeys from Eastern Hungary showed higher $\mathrm{Na}(3.65 \pm 1.19 \mathrm{mg} / \mathrm{kg})$ and $\mathrm{Fe}(0.308 \pm 0.173 \mathrm{mg} / \mathrm{kg})$ concentrations and lower As $(12.8 \pm 6.73 \mu \mathrm{g} / \mathrm{kg})$ concentration than acacia honeys from Western Hungary $(2.64 \pm 0.56 \mathrm{mg} / \mathrm{kg}$ for $\mathrm{Na}$, $0.166 \pm 0.170 \mathrm{mg} / \mathrm{kg}$ for $\mathrm{Fe}$ and $18.0 \pm 6.45 \mu \mathrm{g} / \mathrm{kg}$ for As, respectively).

\section{The effect of storage}

In Hungary the maximum durability of honeys is 2 years. Because of this, the changes in different parameters of five acacia honey samples were determined 2 years after collection. Table 6 contains parameters which showed changes under storage. No change was measured in electrical conductivity, $\mathrm{pH}$, moisture and element contents of samples. Corresponding with the existing literature (White 2000), the diastase activities were lower and HMF contents higher after storage. The reduction was not important in the case of diastase activity, however increases of HMF contents were more significant. Lower proline contents and higher TPCs were measured after storage. Small increases were measured in sucrose content. Colour of samples 1, 3, 4 and 5 was water white $(<9)$ immediately after collecting. Samples 1, 4 and 5 showed a darker colour $(13 \mathrm{~mm}$, $15 \mathrm{~mm}$ and $13 \mathrm{~mm}$, respectively) after 2 years. The colour value of Sample 3 was less than $9 \mathrm{~mm}$ after storage. Sample 2 showed a darker colour with $16 \mathrm{~mm}$ (after collecting) and with $30 \mathrm{~mm}$ (after 2 years).

\section{Conclusion}

Centrifugation and filtration reduced the proline, TPC, electrical conductivity and examined element content of honey samples, which can be ascribed to removal of fragments of the wax capping and comb pieces. Heating had no effect on the mineral content of acacia honeys, but reduced diastase activity and increased HMF at high temperatures. It also reduced total phenolic content and proline content, and increased the colour to a small extent. Honey 
samples adulterated with sugar additives had reduced diastase activity, proline content, TPC (except for ISA and ISE), electrical conductivity, colour, fructose content, B, $\mathrm{Fe}, \mathrm{K}, \mathrm{Mg}, \mathrm{P}, \mathrm{S}$ and $\mathrm{Zn}$ contents, compared with the original acacia honey samples. These adulterated samples had increased $\mathrm{pH}$, moisture (except for FGS and ISE) and sucrose (except for ISE) than the original samples. The adulterant used did not change the values of HMF, glucose (except for SA), As (except for ISA and ISE) or Cd content. Year of collection did not have any effect on the examined physicochemical parameters of acacia honeys, however, the collecting area affected the $\mathrm{Na}, \mathrm{Fe}$ and $\mathrm{As}$ concentrations. Two years storage did not have major effects on the physicochemical properties of acacia honeys, but it reduced diastase activity and proline content and increased HMF content, TPC and colour values.

Acknowledgements Open access funding provided by University of Debrecen (DE). We would like to thank Hungrana Kft., Hungary for sugar products and Gerda Diósi (beekeeper) for samples.

Open Access This article is distributed under the terms of the Creative Commons Attribution 4.0 International License (http://crea tivecommons.org/licenses/by/4.0/), which permits unrestricted use, distribution, and reproduction in any medium, provided you give appropriate credit to the original author(s) and the source, provide a link to the Creative Commons license, and indicate if changes were made.

\section{References}

Almeida-Silva M, Canha N, Galinha C, Dung HM, Freitas MC, Sitoe T (2011) Trace elements in wild and orchard honeys. Appl Radiat Isot 69:1592-1595. https://doi.org/10.1016/j.apradiso. 2011.01.013

Anklam E (1998) A review of the analytical methods to determine the geographical and botanical origin of honey. Food Chem 63:549-562. https://doi.org/10.1016/S0308-8146(98)00057-0

AOAC Official Methods of Analysis (1995a) AOAC official method 969.38 moisture in honey. In: Sugars and sugar products, chapter 44, p 20

AOAC Official Methods of Analysis (1995b) AOAC official method 977.20 separation of sugars in honey liquid chromatographic method. In: Sugars and sugar products, chapter 44, p 25

Bath PK, Singh N (1999) A comparison between Helianthus annuus and Eucalyptus lenceolatus honey. Food Chem 67:389-397. https://doi.org/10.1016/S0308-8146(99)00132-6

Bogdanov S (2009) Harmonised methods of the International Honey Commission. International Honey Commission, pp 1-63

Bogdanov S, Lüllman C, Martin P (1997) Harmonized methods of the European Honey Commission. Apidology (Extra Issue) 1-59

Bogdanov S, Jurendic T, Sieber R, Gallmann P (2008) Honey for nutrition and health: a review. J Am Coll Nutr 27:677-689. https://doi.org/10.1080/07315724.2008.10719745

Bontempo L, Camin F, Ziller L, Perini M, Nicolini G, Larcher R (2015) Isotopic and elemental composition of selected types of Italian honeys. Measurement. https://doi.org/10.1016/j.measure ment.2015.11.022

Can Z, Yildiz O, Sahin H, Turumtay EA, Silici S, Kolyli S (2015) An investigation of Turkish honeys: their physico-chemical properties, antioxidant capacities and phenolic profiles. Food Chem 180:133-141. https://doi.org/10.1016/j.foodchem.2015. 02.024

Cavia MM, Fernandez-Muino MA, Gomez-Alonso E, Montes-Pérez MJ, Huidobro JF, Sancho MT (2002) Evolution of fructose and glucose in honey over one year: influence of induced granulation. Food Chem 78:157-161. https://doi.org/10.1016/S03088146(01)00393-4

Codex Alimentarius Hungaricus 2-100 Directive (2009) Honey with distinctive quality indication

Czipa N, Kovács B (2014) Electrical conductivity of Hungarian honeys. J Food Phys 27:13-20

Czipa N, Borbély M, Győri Z (2012) Proline content of different honey types. Acta Aliment Hung 41:26-32. https://doi.org/10. 1556/AAlim.2011.0002

Di Bella G, Lo Turco V, Potortì AG, Bua GD, Fede MR, Dugo D (2015) Geographical discrimination of Italian honey by multielement analysis with a chemometric approach. J Food Compos Anal 44:25-35. https://doi.org/10.1016/j.jfca.2015.05.003

Council EU Directive 2001/110/EC relating to honey (2002) Official Journal of the European Communities L 010, 0047-0052

Doner LW (1977) The sugars of honey-a review. J Sci Food Agric 28:443-456. https://doi.org/10.1002/jsfa.2740280508

Guler A, Bakan A, Nisbet C, Yavuz O (2007) Determination of important biochemical properties of honey to discriminate pure and adulterated honey with sucrose (Saccharum officinarum L.) syrup. Food Chem 105:1119-1125. https://doi.org/10.1016/j. foodchem.2007.02.024

Hermosín I, Chichón RM, Cabezudo MD (2003) Free amino acid composition and botanical origin of honey. Food Chem 83:263-268. https://doi.org/10.1016/S0308-8146(03)00089-X

Juan-Borrás M, Domenech E, Hellebrandova M, Escriche I (2014) Effect of country origin on physicochemical, sugar and volatile composition of acacia, sunflower and tilia honeys. Food Res Int 60:86-94. https://doi.org/10.1016/j.foodres.2013.11.045

Kaygusuz H, Tezcan F, Ermin FB, Yildiz O, Sahin H, Can Z, Kolayli $S$ (2016) Characterization of Anatolian honeys based on minerals, bioactive components and principal component analysis. LWT Food Sci Technol 68:273-279. https://doi.org/10. 1016/j.lwt.2015.12.005

Kovács B, Győri Z, Prokisch J, Loch J, Dániel P (1996) A study of plant sample preparation and inductively coupled plasma emission spectrometry parameters. Commun Soil Sci Plant Anal 27:1177-1198. https://doi.org/10.1080/00103629609369625

Lampeitl F, Franz K (1997) Méhészkedés. Ulmer \& HOGYF Editio, Budapest

Meda A, Lamien CE, Romito M, Millogo J, Nacoulma OG (2005) Determination of the total phenolic, flavonoid and prolin contents in Burkina Fasan honey, as well as their radical scavering activity. Food Chem 91:571-577. https://doi.org/10. 1016/j.foodchem.2004.10.006

MSZ 6950-3:1977: MÉZ - Mikroszkópos vizsgálat

MSZ 6943-3:1980: Méz fizikai és kémiai vizsgálata. Savfok és pH meghatározása

Nayik GA, Suhag Y, Majid I, Nanda V (2016) Discrimination of high altitude Indian honey by chemometric approach according to their antioxidant properties and macro minerals. J Saudi Soc Agric Sci. https://doi.org/10.1016/j.arabjc.2015.08.017

Nozal MJ, Bernal JL, Toribio L, Jimenez JJ, Martin MT (2001) Highperformance liquid chromatography determination of methyl anthranilate, hydroxymethylfurfural and related compounds in honey. J Chromatogr A 917:95-103. https://doi.org/10.1016/ S0021-9673(01)00702-6

Oddo LP, Bogdanov S (2004) Determination of honey botanical origin: problems and issues. Apidologie 35(1):S2-S3. https://doi. org/10.1051/apido:2004044 
Paszkowsky B, Wilczek A, Szypłowska A, Nakonieczna A, Skierucha W (2014) A low-frequency sensor for determination of honey electrical properties in varying temperature conditions. J Food Eng 138:17-22. https://doi.org/10.1016/j.jfoodeng.2014.04.004

Singh N, Bath PK (1997) Quality evaluation of different types of Indian honey. Food Chem 58:129-133. https://doi.org/10.1016/ S0308-8146(96)00231-2

Singh N, Bath PK (1998) Relationship between heating and hydroxymethylfurfural formation in different honey types. J Food Sci Technol 35(2):154-156

Terrab A, Diez MJ, Hereida FJ (2002) Characterisation of Moroccan unifloral honeys by their physicochemical characteristic. Food
Chem 79:373-379. 8146(02)00189-9

https://doi.org/10.1016/S0308-

Tosi E, Martinet R, Ortega M, Lecaro H, Ré E (2008) Honey diastase activity modified by heating. Food Chem 106:883-887. https:// doi.org/10.1016/j.foodchem.2007.04.025

White JW (1984) Instrumental color classification of honey: collaborative study. J Assoc Off Anal Chem 67(6):1129-1131

White JW (2000) Ask the honey expert. Am Bee J 140:365

Publisher's Note Springer Nature remains neutral with regard to jurisdictional claims in published maps and institutional affiliations. 